\title{
DAMPAK KRISIS EKONOMI TERHADAP PROFITABILITAS AGROINDUSTRI KERIPIK TEMPE DI KABUPATEN TEBO
}

\author{
Dhikdaya Manggala Putra ${ }^{1)}$, Dompak Napitupulu ${ }^{2)}$ dan Elwamendri ${ }^{2)}$ \\ 1) Alumni Program Studi Agribisnis Fakultas Pertanian Universitas Jambi, \\ 2) Dosen Program Studi Agribisnis Fakultas Pertanian Universitas Jambi \\ Email: dhikdaya11@yahoo.com
}

\begin{abstract}
ABSTRAK
Penelitian ini ditunjukan untuk mengetahui seberapa besar pendapatan dan profitabilitas yang di peroleh agroindustri keripik tempe di Kabupaten Tebo sebelum dan saat krisis ekonomi. Pemilihan lokasi penelitian dengan dasar penetapan wilayah secara sengaja (Purposive) dengan pertimbangan lokasi penelitian merupakan daerah agroindustri keripik tempe dengan jumlah 32 unit yang terletak di Kabupaten Tebo. Penelitian dilakukan dari tanggal 16 Juni 2014 sampai tanggal 16 Juli 2014 dengan metode sensus. Hasil penelitian menunjukkan bahwa terjadi penurunan pendapatan saat krisis ekonomi yang dimana sebelum krisis ekonomi rata-rata pendapatan agroindustri keripik tempe sebesar Rp. 55.697.106/tahun dan saat krisis ekonomi rata-rata pendapatan sebesar Rp. 32.694.808/tahun dengan perbedaan pendapatan sebelum dan saat krisis ekonomi sebesar Rp. 23.002.298/tahun. hal itu mengakibatkan ikut menurunnya profitabilitas saat krisis ekonomi dimana rata-rata profitabilitas sebelum krisis ekonomi sebesar 4,80\% /tahun dan saat krisis ekonomi sebesar 3,01\%/tahun dengan perbedaan profitabilitas sebelum dan saat krisis ekonomi sebesar 1,79\%/tahun. Selain itu digunakan analisis uji beda dua rata-rata antara pendapatan dan profitabilitas sebelum krisis ekonomi dan saat krisis ekonomi yang dimana didapat hasil pendapatan dan profitabilitas agroindustri keripik tempe sebelum krisis ekonomi lebih besar dibandingkan dengan pendapatan dan profitabilitas agroindustri saat krisis ekonomi.
\end{abstract}

Kata Kunci : Krisis Ekonomi, Profitabilitas, Agroindustri, Keripik Tempe

\section{ABSTRACT}

This research is aimed to determine income and profitability earned by chips tempe agroindustriy in Tebo District before and during the economic crisis. Site selection research on the basis of the determination of the region deliberately (Purposive) with consideration of the location of the research area is tempe chips agroindustry with total agroindustries number are 32 units located in the Tebo District. Research was conducted from 16th june until 16th july 2014 in census method. The results showed that the decline in income during the economic crisis before the economic crisis in which the average income of tempeh chips agroindustriy Rp 55.697.106/year when the economic crisis and the average income of Rp. 32.694.808/year with the difference of income both before and during the economic crisis amounting to Rp. 23.002.298/year. It resulted in the declining profitability as part of economic crisis where the average profitability before the economic crisis of $4.80 \% / y e a r$ and the present economic crisis amounted to $3.01 \% /$ year with a difference of profitability before and during the economic crisis of $1.79 \% /$ tahun. In addition to two different test analysis used average between income and profitability before the economic crisis and during the economic crisis which had the result of income and profitability of tempe chips agroindustriy for before economic crisis greater than the income and profitability of tempe chips agroindustry during the economic crisis.

Keywords: EconomicCrisis, Profitability, Agroindustry, Tempe Chips 


\section{PENDAHULUAN}

Krisis ekonomi global sebagai dampak dari krisis keuangan Amerika. Kondisi tersebut menyebar dan menjalar keseluruh dunia termasuk di Indonesia yang mengakibatkan rupiah melemah terhadap dolar. hal itu menyebabkan harga bahan pokok meningkat sehingga mempengaruhi pertumbuhan ekonomi Indonesia yang pada akhirnya juga mempengaruhi perekonomian regional. Salah satu bahan yang meningkat adalah kedelai impor.

Harga kedelai impor meningkat di karenakan pengaruh krisis ekonomi global yang terjadi di seluruh dunia termasuk Amerika yang berdampak pada kenaikan harga impor kedelai Amerika. Kenaikan harga kedelai impor tersebut di sebabkan harga kedelai dipasar internasional naik $100 \%$. Harga kedelai di akhir tahun 2007 sebesar US\$300/ton, tetapi pada awal tahun 2008 sudah naik menjadi US\$600/ton (Sinartani, 2008).

Dengan peningkatan harga kedelai yang signifikan maka akan berdampak terhadap penerimaan yang diterima agroindustri berbahan baku kedelai. Hal itu membuat banyak para pelaku usaha agroindustri yang mengandalkan kedelai sebagai bahan baku terpaksa berhenti berproduksi dikarenakan ketidakmampuan pelaku usaha agroindustri untuk mendapatkan laba yang positif bagi agroindustrinya. hal itu di sebabkan oleh biaya produksi meningkat dan tidak diimbangi dengan penerimaan yang baik

Dengan peningkatan harga kedelai yang signifikan maka akan berdampak terhadap penerimaan yang diterima agroindustri berbahan baku kedelai. Hal itu membuat banyak para pelaku usaha agroindustri yang mengandalkan kedelai sebagai bahan baku terpaksa berhenti berproduksi dikarenakan ketidakmampuan pelaku usaha agroindustri untuk mendapatkan laba yang positif bagi agroindustrinya. hal itu di sebabkan oleh biaya produksi meningkat dan tidak diimbangi dengan penerimaan yang baik.

Pada tahun 2013 krisis ekonomi kembali mengguncang Indonesia yang ditandai dengan melemahnya nilai tukar mata uang rupiah terhadap mata uang dolar Amerika Serikat hingga mencapai Rp.12.000 per dolar (Bank Indonesia, 2013). hal itu di karenakan kondisi perekonomian dan pasar uang dalam kondisi tidak stabil. Krisis Ekonomi Jilid 2 pada tahun 2013 mengakibatkan harga bahan pangan semakin meningkat. Harga kedelai mengalami peningkatan tertinggi hingga hampir mencapai Rp. 10.000/Kg (Kementrian Perdagangan). Kondisi tersebut mengakibatkan pelaku agroindustri yang mengandalkan kedelai sebagai bahan baku utama khususnya agroindustri keripik tempe semakin sulit untuk berkembang dan cenderung memilih berhenti berproduksi.

Sebagian besar agroindustri yang mengandalkan kedelai sebagai bahan baku utamanya, menggunakan bahan baku kedelai impor yang sebagian besar di impor dari Amerika. Oleh karena itu agroindustri yang menggunakan bahan baku kedelai di Indonesia berpeluang terkena dampak krisis ekonomi yang mengakibatkan harga kedelai impor meningkat tajam di pasaran yang akhirnya akan berdampak pada kondisi finansial agroindustri yang mengandalkan kedelai sebagai bahan baku.

Krisis ekonomi membuat banyak pelaku usaha yang menggadalkan bahan baku kedelai berhenti berproduksi. Hal itu dikarenakan pendapatan dari agroindustri menurun, Akibat dari bahan baku (kedelai impor) yang digunakan mengalami kenaikan harga sehingga membuat biaya produksi meningkat dan tidak diimbangi dengan penerimaan yang positif sehingga berdampak pada menurunnya kemampuan agroindustri keripik tempe untuk mendapatkan laba (Profitabilitas).

Provinsi Jambi sebagai bagian dari wilayah Indonesia memiliki sumberdaya alam yang relatif besar. Untuk mendukung perkembangan industri pengolahan hasil pertanian atau agroindustri dengan menitik beratkan pada peningkatan potensi yang ada secara optimal, meningkatkan efisiensi dan nilai tambah, diversifikasi produk serta menumbuhkan industri kecil yang baru dan salah bentuk agroindustri yang dapat dikembangkan adalah agroindustri pangan.

Salah satu komoditas pangan yang dapat diolah menjadi produk baru yang memiliki nilai tambah adalah kedelai. Saat ini komoditi yang kaya dengan protein ini sangat diminati sebagian besar masyarakat Provinsi Jambi karena kandungan gizi yang tingggi di dalamnya. Selain itu komoditi ini merupakan produk pertanian yang memiliki prospek baik untuk masa yang akan datang dan sekaligus 
menunjukan bahwa komoditi kedelai merupakan produk berdaya guna dan merupakan bahan baku dari berbagai industri. Dalam hal ini terlihat dari mulai banyaknya industri rumah tangga yang menggunakan bahan baku kedelai, mulai dari tempe, tahu, tauco, kecap, susu, sampai keripik tempe.

Di Provinsi Jambi salah satu kabupaten yang perkembangan agroindutrinya sedang meningkat adalah Kabupaten Tebo yang dimana terdapat 7 jenis agroindustri pangan. Salah satunya adalah agroindustri keripik tempe.

Keripik tempe merupakan produk yang berbahan dasar kedelai yang banyak diminati masyarakat Provinsi jambi khususnya di Kabupaten Tebo. Hal ini dikarenakan keripik tempe merupakan produk agroindustri yang memiliki tempat dihati masyarakat, baik sebagai menu pelengkap makanan pokok juga dapat dinikmati sebagai makanan ringan.

Meski banyak pelaku agroindustri tempe tahu yang berhenti berproduksi di Kabupaten Tebo akibat dari kenaikan harga kedelai, namun produksi keripik tempe di Kabupaten Tebo yang masyarakatnya mengandalkan usaha keripik tempe sebagai mata pencarian yang juga mengandalkan kedelai impor untuk keripik tempenya tetap bertahan.

Agroindustri keripik tempe dapat bertahan di tengah krisis ekonomi yang melanda yang membuat banyak pelaku usaha yang menggadalkan bahan baku kedelai berhenti berproduksi. Itu dikarenakan kemampuan agroindustri keripik tempe untuk mendapatkan laba (Profitabilitas) yang cukup positif bagi agroindustrinya yang akhirnya berdampak pada pendapatan agroindustri keripik tempe. hal itu yang membuat pelaku usaha dapat bertahan dengan serangan krisis ekonomi yang melanda dunia saat ini.

Bagi perusahaan atau usaha pada umumnya masalah profitabilitas lebih penting daripada masalah laba, karena masalah laba yang besar saja belumlah merupakan ukuran bahwa perusahaan itu telah dapat bekerja dengan efisien. Dengan demikian yang harus diperhatikan oleh perusahaan tidak hanya bagaimana memperbesar laba tetapi yang lebih penting adalah usaha untuk mempertinggi profitabilitasnya.

Adapun tujuan dari penelitian ini untuk mengetahui seberapa besar pendapatan dan profitabilitas sebelum krisis ekonomi dengan saat krisis ekonomi di Kabupaten Tebo.

\section{METODE PENELITIAN}

Penelitian ini dilaksanakan di Kabupaten Tebo. Pemilihan dan penentuan lokasi dilakukan secara sengaja (Purposive) didasarkan atas pertimbangan bahwa banyak terdapat agroindustri keripik tempe Kabupaten Tebo dan jumlahnya sebanyak 32 unit usaha agroindustri keripik tempe. Sampel berjumlah 32 karena menggunakan metode sensus.

Penelitian ini menganalisis tentang pendapatan dan profitabilitas agroindustri keripik tempe sebelum dan saat krisis ekonomi. Jadi, ruang lingkup penelitian ini adalah agroindustri keripik tempe karena bahan baku utamanya adalah kedelai impor. Sedangkan komoditas kedelai tersebut mengalami kenaikan harga akibat dari krisis ekonomi yang terjadi di Negara pengimpor kedelai yang dalam hal ini adalah Amerika Serikat.

Penelitian ini dilaksanakan dari tanggal 16 Juni 2014 sampai dengan tanggal 16 Juli 2014. Metode pengumpulan data dilakukan dengan mengajukan pertanyaan-pertanyaan kepada pelaku usaha agroindustri dengan panduan kuisioner. Selain itu, pengumpulan data juga diambil melalui Badan Pusat Statistik..

Data yang diperoleh dari responden terlebih dahulu dikumpulkan dan disederhanakan secara tabulasi, kemudian di analisis secara deskriptif. Selanjutnya analisis yang dilakukan dalam penelitian ini adalah analisis pendapatan dan profitabilitas.

$T R=Q \times P$

Dimana : TR $=$ Total Penerimaan 


$$
\begin{aligned}
& \mathrm{P}=\operatorname{Harga}(\mathrm{Rp} / \mathrm{kg}) \\
& \mathrm{Q}=\text { Jumlah Produksi }(\mathrm{kg})
\end{aligned}
$$

$\mathrm{TC}=\mathrm{FC}+\mathrm{VC}$

$$
\begin{aligned}
\text { Dimana }: \text { TC } & =\text { Total Biaya } \\
\mathrm{FC} & =\text { Biaya tetap }(\mathrm{Rp}) \\
\mathrm{VC} & =\text { Biaya variabel }(\mathrm{Rp})
\end{aligned}
$$

$P d=T R-T C$

Dimana : $P d=$ Pendapatan Usahatani $(R p)$

$\mathrm{TR}=$ Total Penerimaan Usahatani (Rp)

$\mathrm{TC}=$ Total Biaya Usahatani $(\mathrm{Rp})$

Profitabilitas $=\frac{\pi}{T C} \times 100 \%$

Dimana: $\pi=$ Pendapatan (Rp)

$\mathrm{TC}=$ Biaya total $(\mathrm{Rp})$

Selain itu untuk mengetahui apakah pendapatan dan profitabilitas agroindustri keripik tempe sebelum krisis ekonomi lebih besar dari pendapatan dan profitabilitas saat krisis ekonomi, dilakukan pengujian sebagai berikut :

uji beda dua rata-rata dengan rumus :

$$
\text { thitung }=\frac{\bar{x}_{1}-\bar{x}_{2}}{\sqrt{\frac{\left(n_{1}-1\right) S_{1}^{2}+\left(n_{2}-1\right) S_{2}^{2}}{n_{1}+n_{2}-2} \cdot \sqrt{\frac{1}{n_{1}}+\frac{1}{n_{2}}}}}
$$

keterangan :

$\mathrm{x}_{1}$ = rata-rata kelompok 1

$\mathrm{x}_{2}=$ rata-rata kelompok 2

$s_{1}=$ Standar Deviasi kelompok 1

$s_{2}=$ Standar deviasi kelompok 2

$n_{1}$ = banyaknya sampel di kelompok 1

$n_{2}=$ banyaknya sampel di kelompok 2

Kaidah pengambilan keputusan :

Ho terima apabila thitung $\leq \mathrm{t}$ tabel

Ha terima apabila $t$ hitung $>t$ tabel

\section{HASIL DAN PEMBAHASAN}

\section{Biaya yang dikeluarkan Agroindustri Keripik Tempe}

Biaya yang dikeluarkan oleh agroindustri keripik tempe di lokasi penelitian meliputi dua bagian yaitu biaya produksi langsung dan biaya non produksi. Biaya produksi langsung merupakan biaya yang dikeluarkan argoindustri keripik tempe dan berhubungan langsung dengan proses produksi yang mengubah bahan baku menjadi barang jadi. Sedangkan biaya non produksi merupakan biaya 
yang dikeluarkan setelah proses produksi selesai. Biaya-biaya yang termasuk dalam proses produksi langsung adalah biaya bahan baku, biaya bahan penolong, biaya tenaga kerja, dan biaya penyusutan alat. Sedangkan yang termasuk dalam biaya non produksi adalah biaya pemasaran.

Biaya bahan baku merupakan biaya yang harus dikeluarkan untuk memperoleh bahan baku. Pada agroindustri keripik tempe yang diteliti, biaya untuk bahan baku yang dikeluarkan adalah untuk membayar harga bahan baku yaitu harga pembelian kacang kedelai. Dari hasil penelitian terlihat bahwa biaya bahan baku kedelai untuk setiap agroindustri bervariasi. Hal ini dipengaruhi oleh kebijakan setiap agroindustri yang menyesuaikan jumlah produksi yang ingin dihasilkan dengan modal yang tersedia. Sebelum krisis ekonomi rata-rata biaya yang dikeluarkan oleh setiap agroindustri untuk membeli kedelai adalah Rp. 43.520.321/tahun. Bila dibandingkan dengan biaya rata-rata bahan baku sebelum krisis ekonomi, biaya rata-rata pada masa krisis ekonomi mengalami kenaikan yaitu sebesar Rp. 44.147.775/tahun.

Bahan penolong merupakan bahan-bahan yang juga menjadi bagian dari produk jadi tetapi jumlahnya relatif kecil. Pada proses pengolahan kripik tempe yang menjadi bahan penolong yaitu tepung, telur, minyak goreng, bawang putih, plastik dan kayu bakar. Biaya bahan penolong merupakan biaya yang dikeluarkan untuk membeli bahan-bahan tersebut. Dari hasil penelitian Biaya yang dikeluarkan oleh setiap agroindustri bervariasi jumlahnya. Hal ini tergantung dari banyaknya bahan baku yang digunakan dan jumlah produksi yang diinginkan setiap agroindustri. Rata-rata biaya penggunaan bahan penolong sebelum krisis ekonomi adalah Rp. 5.720.831/tahun sedangkan ratarata biaya pengguanaan bahan penolong setiap agroindustri di Kabupaten Tebo pada saat krisis ekonomi adalah sebesar Rp. 5.340.694/tahun. Hal tersebut memperlihatkan bagaimana penurunan penggunaan bahan penolong di setiap agroindustri pada saat krisis ekonomi bila dibandingkan dengan sebelum krisis ekonomi.

Biaya tenaga kerja merupakan gaji atau upah yang diberikan kepada tenaga kerja yang terlibat dalam pengolahan produk. Pada agroindustri keripik tempe di lokasi penelitian, tenaga kerja yang memerlukan biaya adalah tenaga kerja yang terlibah langsung dalam proses produksi keripik tempe. Dari hasil penelitian terlihat bahwa jumlah rata-rata gaji/upah yang diberikan oleh setiap agroindustri terjadi penurunan pada saat krisis ekonomi dimana saat sebelum krisis ekonomi sebesar Rp. 10.108.929/tahun dan pada saat krisis ekonomi sebesar Rp. 8.608.929/tahun. Hal ini terjadi akibat dari strategi agroindustri untuk mengurangi tenaga kerja agar biaya tenaga kerja dapat dikurangi dan menekan biaya pengeluaran agroindustri.

Biaya pemasaran merupakan biaya-biaya yang terjadi untuk melaksanakan kegiatan pemasaran produk. Pada agroindustri di lokasi penelitian, biaya pemasaran tersebut dikeluarkan untuk membayar biaya transportasi yang digunakan agroindustri untuk menjual keripik tempe ke pasar Tanggo Rajo Tebo dan pasar Rimbo. Dari hasil penelitian menjelaskan jumlah biaya pemasaran yang dikeluakan oleh setiap agroindustri sebelum dan pada saat krisis ekonomi. Rata-rata biaya pemasaran untuk setiap agroindustri keripik tempe di Kabupaten Tebo sebelum krisis ekonomi adalah sebesar Rp. 560.063/tahun dan pada saat krisis ekonomi sebesar Rp. 687.616/tahun. Peningkatan rata-rata biaya pemasaran pada masa krisis ekonomi terjadi akibat dari kenaikan harga bahan bakar minyak yang di tetapkan pemerintah pada tahun 2013 dimana yang sebelumnya Rp.4.500/liter menjadi Rp.6.500/liter.

Penyusutan adalah suatu sistem yang bertujuan untuk mengalokasikan biaya atau nilai lain suatu peralatan. Selama masa ekonomisnya. Berdasarkan pengamatan yang dilakukan, nilai penyusutan dihitung berdasarkan taksiran umur ekonomisnya dan jumlahnya sama setiap tahunnya. Nilai penyusutan setiap agroindustri berbeda-beda sesuai dengan harga beli dan taksiran umur ekonomis dari setiap alat yang digunakan dalam proses pembuatan keripik tempe.

\section{Produksi Keripik Tempe}

Dalam penelitian ini yang dimaksut dengan produksi adalah hasil produksi fisik dalam bentuk keripik tempe yang dihasilkan oleh agroindustri keripik tempe selama penelitian berlangsung dan 
dihitung dalam satuan kilogram $(\mathrm{kg})$. Jumlah produksi antara satu agroindustri dengan agroindustri lainnya akan berbeda. Hal ini disebabkan karena perbedaan penggunaan jumlah bahan baku dalam pengolahan keripik tempe oleh setiap agroindustri. Dari hasil penelitian dapat di jelaskan bahwa ratarata jumlah produksi yang digunakan pada masa krisis ekonomi mengalami penurunan dibandingkan pada saat sebelum krisis ekonomi yang dimana jumlah rata-rata produksi setalah krisis ekonomi adalah $4794,19 \mathrm{~kg} /$ tahun dan sebelum krisis ekonomi adalah 4384,19 kg/tahun. Penurunan ini disebabkan biaya produksi keripik tempe meningkat sementara produsen tidak mampu menaikan harga produk terlalu tinggi atau minimal setara dengan kenaikan biaya produksi tersebut. Hal itu yang membuat produsen membuat strategi untuk menurunkan produksi dengan tujuan menekan biaya pengeluaran.

\section{Penerimaan Agroindustri Keripik Tempe}

Proses produksi yang dilakukan oleh seorang produsen akan menghasilkan sejumlah barang, atau produk. Produk inilah yang jumlah barang yang akan dijual dan hasilnya merupakan jumlah penerimaan bagi seorang produsen. Jadi pengertian penerimaan adalah sejumlah uang yang diterima oleh perusahaan atas penjualan produk yang dihasilkan. Oleh sebab itu jumlah penerimaan ditentukan oleh dua faktor, yaitu jumlah produk (barang yang dihasilkan) dan harga produk tersebut.

Jadi semakin banyak jumlah barang yang dijual maka semakin besar jumlah penerimaan. Dari hasil penelitian di dapatkan rata-rata jumlah produksi sebelum krisis ekonomi sebesar 4794,19 $\mathrm{kg} /$ tahun dengan rata-rata harga $\mathrm{Rp}$. 33.687,5/tahun dan rata-rata jumlah produksi saat krisis ekonomi sebesar 4384,19 kg/tahun dengan rata-rata harga Rp. 34.968,7/tahun.

Rata-rata penerimaan agroindustri keripik tempe di Kabupaten Tebo sebelum krisis ekonomi adalah Rp. 180.226.500/tahun. Sedangkan penerimaan agroindustri keripik tempe pada saat krisis ekonomi terjadi penurunan menjadi Rp. 153.339.125/tahun penurunan ini terjadi akibat dari banyaknya agroindustri menurunkan jumlah produksinya yang bertujuan untuk menekan tingkat pengeluaran yang tinggi dan akan tidak sebanding dengan pemasukan yang didapatkan. Besarnya harga yang ditawarkan oleh setiap agroindustri berbeda. Hal ini terjadi akibat dari strategi agroindustri yang bervariasi menaikan harga produk dikarenakan krisis ekonomi. Akan tetapi peningkatan tersebut tidak sebanding dengan kenaikan harga kedelai karena para pengrajin tidak berani mengambil resiko adanya keripik yang tidak terjual.

\section{Pendapatan Agroindustri Keripik Tempe}

Pendapatan merupakan tujuan utama dari setiap kegiatan usaha, termasuk agroindustri keripik tempe. Pendapatan adalah selisih antara total penerimaan dengan total biaya yang dikeluarkan (Soekartawi, 1994). Total penerimaan diperoleh dari perkalian antara jumlah keripik tempe yang dihasilkan dengan harga jual keripik tempe. Sedangkan biaya merupakan jumlah semua biaya yang dikeluarkan oleh agroindustri keripik tempe yaitu biaya bahan baku, bahan penolong, biaya tenaga kerja, biaya penyusutan alat, dan biaya pemasaran.

Berdasarkan hasil penelitian rata-rata pendapatan yang diterima agroindustri keripik tempe sebelum krisis ekonomi adalah Rp. 55.697.106/tahun. Jumlah ini lebih tinggi bila dibandingkan dengan pendapatan agroindustri keripik tempe pada saat krisis ekonomi yang hanya mencapai Rp. 32.694.808/tahun. Penurunan pendapatan ini disebabkan meningkatnya harga kedelai impor sebagai bahan baku yang digunakan oleh setiap agroindustri. Hal ini senada dengan hasil penelitian Kurniawan (2010) yang menyatakan bahwa krisis global berdampak terjadinya penurunan pendapatan terhapap agroindustri tempe. Pendapatan sebelum krisis gelobal Rp. 6.734.409,04/bulan sedangkan saat krisis global 1.530.940,94/bulan dan yang membedakan dari penelitian ini adalah perbedaan jumlah pendapatan dari agroindustri.

Perbedaan pendapatan agroindustri keripik tempe di Kabupaten Tebo sebelum dan saat krisis ekonomi dapat dilihat dengan menggunakan uji beda dua rata-rata dengan menggunakan analisa uji t. 
Sebelum dilakukan analisis dengan uji $\mathrm{t}$, terlebih dahulu melakukan uji kesamaan varian (homogenitas) dengan $\mathrm{F}$ test, hasil dari $\mathrm{F}$ test adalah yaitu 4,255 dengan nilai signifikan $\mathrm{F}$ hitung $(0,43)>F$ tabel $(0,05)$, maka Ho diterima. Hasil uji $F$ test menunjukkan bahwa varian rata-rata pendapatan agroindustri keripik tempe sebelum dan saat krisis ekonomi adalah sama, sehingga uji $t$ yang digunakan yaitu uji t Equal Variance Assumed (diasumsikan varian sama) dan didapat nilai t-test hitung pada pendapatan adalah 2,363. Dengan derajat kebebasan (df) $n-2$ atau 64-2 $=62$, maka diperoleh nilai $t$ tabel sebesar 1,998 . Nilai t hitung $>t$ tabel $(2,363>1,998)$ maka Ho ditolak, artinya bahwa ada perbedaan pendapatan agroindustri keripik sebelum krisis ekonomi dan pendapatan agroindustri keripik tempe saat krisis ekonomi. Perbedaan rata-rata (mean diference) sebesar $23002298,07(55697106,21$ - 32694808,14) dan perbedaan berkisar antara 3541462,43 sampai 42463133,70 .

\section{Profitabilitas Agroindustri Keripik Tempe}

Bagi perusahaan pada umumnya masalah profitabilitas lebih penting daripada masalah laba, karena masalah laba yang besar saja belumlah merupakan ukuran bahwa prusahaan itu telah dapat bekerja dengan efisien. Dengan demikian yang harus diperhatikan oleh perusahaan tidak hanya bagaimana memperbesar laba tetapi yang lebih penting adalah usaha untuk mempertinggi profitabilitasnya. Besar kecilnya profitabilitas ditentukan oleh dua faktor, yaitu hasil penjualan dan keuntungan usaha. Besar kecilnya keuntungan tergantung pada pendapatan yang merupakan selisih dari penjualan dikurangi dengan biaya usaha (Riyanto, 1994).

Kelangsungan hidup suatu agroindustri ditentukan oleh kemempuan agroindustri tersebut untuk mendapatkan keuntungan atau profitabilitas yang dihasilkan dari pengorbanan sumber daya untuk menghasilkan produk atau jasa. Profitabilitas merupakan hasil bagi antara pendapatan usaha dengan biaya total yang dinyatakan dalam persen.

Dari hasil penelitian rata-rata profitabilitas atau tingkat keuntungan dari agroindustri keripik tempe di Kabupaten Tebo sebelum krisis ekonomi sebesar 4,80\%, yang berarti setiap modal sebesar Rp 100,00 yang diinvestasikan akan diperoleh keuntungan Rp 4,80. Misalnya saja, awal pengusaha agroindustri keripik tempe mengeluarkan modal sebesar Rp 100.000,00 maka pengusaha akan

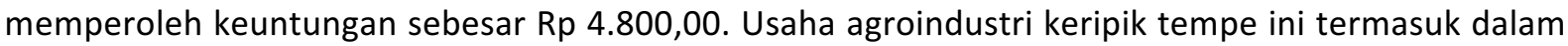
kriteria menguntungkan karena memiliki nilai profitabilitas lebih dari nol. hal ini sesuai dengan konsep yang dipaparkan oleh Riyanto (1997) bahwa Kriteria yang digunakan dalam perhitungan profitabilitas adalah : (1) Profitabilitas $>0$ berarti usaha yang diusahakan menguntungkan, (2) Profitabilitas $=0$ berarti usaha industri keripik belut yang diusahakan mengalami BEP (impas), (3) Profitabilitas $<0$ berarti industri keripik belut yang diusahakan tidak menguntungkan.

Pada saat krisis ekonomi rata-rata profitabilitas agroindustri mengalami penurunan dengan rata-rata profitabilitas sebesar 3,01\% meskipun masih termasuk dalam kriteria menguntungkan karena memiliki nilai profitabilitas lebih dari nol namun jika dibandingkan dengan profitabilitas sebelum krisis ekonomi profitabilitas agroindustri menurun. Hal itu berdampak negatif terhadap perkembangan agroindustri di Kabupaten Tebo karna jika profitabilitas semakin menurun maka akan diikuti jumlah agroindustri semakin menurun.

Dari hasil analisis $t$ test didapatkan nilai t-test hitung pada profitabilitas adalah 3,752. Dengan derajat kebebasan (df) $\mathrm{n}-2$ atau 64-2 $=62$, maka diperoleh nilai t tabel sebesar 1,998. Nilai t hitung $>\mathrm{t}$ tabel $(3,752>1,998)$ maka Ho ditolak, artinya bahwa ada perbedaan tingkat profitabilitas agroindustri keripik sebelum krisis ekonomi dan profitabilitas agroindustri keripik tempe saat krisis ekonomi. Perbedaan rata-rata (mean diference) sebesar 1,793 $(4,800-3,007)$ dan perbedaan berkisar antara 0,83791 sampai 2,74834 .

Dari hasil penelitian menunjukan bahwa profitabilitas sebelum krisis ekonomi lebih besar dibandingkan dengan saat krisis ekonomi. Hal ini di karenakan pengaruh dari menurunnya pendapatan saat krisis ekonomi yang berimbas pada profitabilitas saat krisis ekonomi. Pengaruh 
pendapatan terhadap profitabilitas ini sesuai dengan rumus mencari profitabilitas dari Gasperz (1999) yaitu Pendapatan dibagi Biaya Total dikali 100. Dikarenakan dari hasil penelitian pendapatan saat krisis ekonomi menurun sehingga membuat profitabilitas saat krisis ekonomi ikut menurun.

\section{KESIMPULAN}

Terdapat perbedaan secara nyata dalam hal pendapatan dan profitabilitas agroindustri keripik tempe sebelum krisis ekonomi dengan saat krisis ekonomi. Rata-rata pendapatan agroindustri keripik tempe di Kabupaten Tebo sebelum krisis ekonomi (Rp.55.697.106/tahun) lebih besar dari pendapatan pada saat krisis ekonomi (Rp.32.694.808/tahun) penurunan pendapatan sebesar $41 \%$. Rata-rata profitabilitas agroindustri keripik tempe di Kabupaten Tebo sebelum krisis ekonomi $(4,80 \%$ /tahun), lebih besar dari profitabilitas pada saat krisis ekonomi (3,01\% /tahun) penurunan profitabilitas sebesar 1,79\%/tahun. Penurunan pendapatan dan profitabilitas akibat krisis ekonomi tersebut terutama di sebabkan oleh harga bahan baku kedelai impor yang naik yang berdampak pada biaya produksi yang ikut naik yang akhirnya berpengaruh terhadap pendapatan dan profitabilitas agroindustri keripik tempe.

\section{DAFTAR PUSTAKA}

Badan Pusat Statistik, 2013.Impor Kedelai Menurut Asal Negara. www.bps.go.id. Diakses 28 januari 2014.

Dinas Perindustrian, Perdagangan, Koperasi dan Ukm Kabupaten Tebo. 2013. Data Agroindustri Keripik Tempe Kabupaten Tebo 2013, Jambi.

Downey, Erickson. 1992. Manajemen Agribisnis. Penerbit Erlangga, Jakarta.

Johannes, 1983. Pengantar Matematika Ekonomi. Intermasa, Jakarta.

Kementerian perdagangan, 2013. Perkembangan Harga Kedelai Lokal dan Impor Tahun 2009 hingga 2013. www.kemendag.go.id. Diakses 29 Januari 2014.

Kurniawan Rully, 2010. Dampak Krisis Global Terhadap Pendapatan Agroindustri Tempe Di Kelurahan Rajawali Kota Jambi. Skripsi Jurusan Sosial Ekonomi Pertanian. Fakultas Pertanian. Universitas Jambi (Tidak Dipublikasikan).

Riyanto, B. dan B, Krisnamurthi, 1993. Pengembangan Agribisnis dan Peran Agroindustri Sebagai Leading Sector. Dalam Skripsi Yenny Mailya 2009 Santi Fakultas Pertanian Universitas Sebelasas Maret Surakarta.

Sinartani, 2008. Kedelai. http//: www. Sinartanionline.org. Diakses 28 Januari 2014.

Soekartawi, 2000. Pengantar Agroindustri. PT Raja Grafindo, Jakarta.

Sugiono, 2012. Statistika untuk Penelitian. Alfabeta.Bandung. 